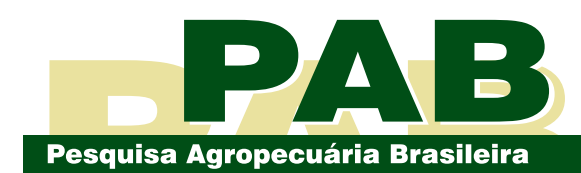

ISSN 1678-3921

Journal homepage: www.embrapa.br/pab

For manuscript submission and journal contents, access: www.scielo.br/pab

Jeferson Araújo Silva ${ }^{(1 凶)}($ iD

Antonio Félix da Costa ${ }^{(2)}$ (iD,

Ana Maria Benko-Iseppon ${ }^{(3)}$ (iD,

Lílian Margarete Paes Guimarães(1) (iD),

Diego Arruda Huggins de Sá Leitão(1) (D) and

Alessandro $\mathrm{Nicoli}^{(4)}$ (iD

(1) Universidade Federal Rural de Pernambuco, Departamento de Agronomia, Programa de PósGraduação em Fitopatologia, Rua Dom Manuel de Medeiros, s/no, Dois Irmãos, CEP 52171-900 Recife, PE, Brazil.

E-mail: jefersonaraujo.bio@gmail.com, lilianmguimaraes@gmail.com,

hugginsdiego@gmail.com

(2) Instituto Agronômico de Pernambuco, Avenida General San Martin, no 1.371, Bongi, CEP 50761-000 Recife, PE, Brazil.

E-mail: felix.antonio@ipa.br

(3) Universidade Federal de Pernambuco, Centro de Biociências, Departamento de Genética, Avenida Professor Moraes Rego, s/no, Cidade Universitária, CEP 50670-420 Recife, PE, Brazil.

E-mail: ana.iseppon@gmail.com

(4) Universidade Federal dos Vales do Jequitinhonha e Mucuri, Instituto de Ciências Agrárias, Avenida Universitária, no 1.000, Universitários CEP 38610-000 Unaí, MG, Brazil. E-mail: alessandro.nicoli@ufvjm.edu.br

$\bowtie$ Corresponding author

Received

June 30, 2020

Accepted

December 22, 2020

How to cite

SILVA, J.A.; COSTA, A.F. da; BENKO-

ISEPPON, A.M.; GUIMARÃES, L.M.P.; LEITÃO,

D.A.H. de S.; NICOLI, A. Inheritance of cowpea resistance to Cowpea aphid-borne mosaic virus. Pesquisa Agropecuária Brasileira, v. 56 , e02109, 2021. DOI: https://doi.org/10.1590/ S1678-3921.pab2021.v56.02109.

\section{Inheritance of cowpea resistance to Cowpea aphid-borne mosaic virus}

\begin{abstract}
The objective of this work was to evaluate the inheritance of resistance to Cowpea aphid-borne mosaic virus (CABMV) in cowpea (Vigna unguiculata). The study was performed between parental genotypes IT85F-2687 (resistant) and 'BR-14 Mulato' (susceptible), generating $\mathrm{F}_{1}, \mathrm{~F}_{2}$, and $\mathrm{F}_{7}$ populations and backcrosses with both parental genotypes. CABMV was inoculated on plants from all generations, which were then evaluated through visual inspection and description of characteristic symptoms. A chisquare test was performed after the phenotypic classification of all plants. A segregation proportion of 1:3 (resistant:susceptible) in population $F_{2}$ and of 1:1 in population $F_{7}$ was accepted, showing a recessive monogenic inheritance.
\end{abstract}

Index terms: Vigna unguiculata, CABMV, genetic control.

\section{Herança de resistência do feijão-caupi ao Cowpea aphid-borne mosaic virus}

Resumo - O objetivo deste trabalho foi avaliar a herança de resistência ao Cowpea aphid-borne mosaic virus (CABMV) em feijão-caupi (Vigna unguiculata). O estudo foi realizado entre os genótipos parentais IT85F-2687 (resistente) e 'BR-14 Mulato' (suscetível), tendo-se obtido populações $F_{1}, F_{2}$ e $\mathrm{F}_{7}$ e retrocruzamentos com ambos os genótipos parentais. O CABMV foi inoculado nas plantas de todas as gerações, que foram, então, avaliadas por inspeção visual e pela descrição dos sintomas característicos. $\mathrm{O}$ teste do qui-quadrado foi aplicado após a classificação fenotípica de todas as plantas. Uma proporção de segregação de 1:3 (resistente:suscetível) na população $F_{2}$ e de 1:1 na população $F_{7}$ foi aceita, tendo indicado herança monogênica recessiva.

Termos para indexação: Vigna unguiculata, CABMV, controle genético.

Cowpea [Vigna unguiculata (L.) Walp.] belongs to the Fabaceae family and is an herbaceous annual crop, grown mainly in dry regions. Its production is impaired by several abiotic and biotic factors that cause yield reductions, such as the aphid Aphis craccivora Koch and fungal, bacterial, and viral diseases. Cowpea mosaic caused by the Cowpea aphid-borne mosaic virus (CABMV) is a major disease that considerably reduces crop yield, standing out for its worldwide distribution (Barros et al., 2013; Boukar et al., 2019).

The use of resistant varieties is a useful method to manage CABMV, and some genotypes have already been identified in previous studies: IT85F-2687, Patativa, TE97-309G-22, TE97-309G-9, Tvu 379, Tvu 382, Tvu 410, and Tvu 966 (Oliveira et al., 2012; Barros et al., 2013). 
The IT85F-2687 line was introduced by International Institute of Tropical Agriculture, located in Ibadan, Nigeria (Lima Filho et al., 2013), and has also been reported as resistant to CABMV by other authors (Oliveira et al., 2012). However, the genetic nature that controls resistance to CABMV has not been determined yet. Orawu et al. (2013) pointed out that a single recessive gene is responsible for resistance, while Antoine et al. (2016) found a dominant monogenic inheritance.

Up to now, there are no known studies of inheritance involving IT85F-2687 and CABMV. As this line is well known for its resistant trait to the virus, understanding the genetic nature of its resistance is essential for improvement program planning, aiming to incorporate resistance into cultivars with desirable agronomic traits.

The objective of this work was to evaluate the inheritance of resistance to CABMV in cowpea.

The experiment was carried out by crossing the IT85F-2687 and 'BR-14 Mulato' parental genotypes (resistant and susceptible to CABMV, respectively), both from Embrapa Meio-Norte and stored in the cowpea germplasm bank of Instituto Agronômico de Pernambuco (IPA) from July 2017 to April 2020. Genotype IT85F-2687 has white flowers and was used as the female parent, whereas 'BR-14 Mulato' has purple flowers and was used as the male parent. After the crossing between the parental genotypes, $F_{1}$ seed were obtained and the $\mathrm{F}_{2}$ population was generated by selffecundating plants grown from $F_{1}$ seed. Generation $F_{1}$ was backcrossed with resistant (backcrossing resistant $-\mathrm{BC}_{\mathrm{R}}$ ) and susceptible (backcrossing susceptible $\mathrm{BC}_{\mathrm{S}}$ ) parents.

The crossings were performed in clayey soil beds in a greenhouse, where plants were irrigated daily, temperature ranged from 22 to $31^{\circ} \mathrm{C}$, and air relative humidity ranged from 69 to $82 \%$. First, the open and fully-developed flowers were collected in the morning and kept under refrigeration inside a fridge, at $5^{\circ} \mathrm{C}$, for further use at the end of the evening, when the flower bud was emasculated and pollinated (Zary \& Miller Júnior, 1982). Proper crossings were confirmed if the plants from generation $F_{1}$ showed purple flowers (dominant morphological marker), and the plants with white flowers were discarded.

A population of recombinant inbred lines (RILs) within generation $\mathrm{F}_{7}$ was obtained through the single- pod descent procedure (Borém \& Miranda, 2013). The progress of generation $F_{2}$ to $F_{6}$ was evaluated at the experimental station of IPA, located in the municipality of Belém de São Francisco, in the state of Pernambuco, Brazil, between June 2018 and February 2020. Every dry and good quality pod was collected, and the $\mathrm{F}_{7}$ seed of each RIL were stored.

After obtaining all crossings, generations $\mathrm{F}_{1}, \mathrm{~F}_{2}$, and $\mathrm{F}_{7}$, and both backcrossing $\left(\mathrm{BC}_{\mathrm{R}}\right.$ and $\left.\mathrm{BC}_{\mathrm{S}}\right)$, the resulting plants from all generations were inoculated with CABMV to assess resistance inheritance. The experiment was conducted in a randomized complete block design, in which each replicate consisted of a pot containing five plants. Plants of each population were inoculated: 100 of each parental genotype, 200 of each backcrossing, 200 of generation $F_{1}, 800$ of generation $\mathrm{F}_{2}$, and 10 of each 386 RILs (Table 1). The CABMV isolate was obtained from cowpea plants susceptible to the virus, which had been infected and were kept in the greenhouse, and then it was properly identified through the enzyme-linked immunosorbent assay at the Plant Virology Laboratory of Universidade Federal Rural de Pernambuco.

For planting, seven cowpea seed were sown per pot, containing $4 \mathrm{~L}$ clayey soil. Seven days after planting, the plants were thinned down to five per pot and leaves were powdered with a small amount of carborundum 600 mesh. CABMV was inoculated seven days after planting by rubbing a leaf extract produced by macerating infected leaves in a $0.01 \mathrm{~mol} \mathrm{~L}^{-1}$ phosphate buffer solution $(1.0 \mathrm{~g}$ leaf tissue per $9.0 \mathrm{~mL}$ buffer solution) (Oliveira et al., 2012). Subsequently, leaves were washed with sterilized distilled water to remove inoculum excess. Control plants were composed of the 'BR-14 Mulato' and IT85F-2687 cowpea genotypes, considered susceptible and resistant to CABMV, respectively (Oliveira et al., 2012).

Disease symptoms were evaluated through regular inspections of the inoculated plants, by observing and recording the emergence and development of any symptom, such as blisters, vein clearing, chlorosis, or mosaic (Vale \& Lima, 1994). Plants with visible symptoms were classified as susceptible, and those without symptoms, as resistant (Lima et al., 2011). After the phenotypic classification - as resistant or susceptible - of the plants in the segregate generations, a non-parametric chi-square test was performed to fit simple genetic models, which originated a testable 
hypothesis, comparing observed and expected frequencies in discreet categories to estimate the number of genes involved in resistance control, using the Genes software (Cruz, 2013).

Most plants from the resistant parent (IT85F-2687) did not show any disease symptoms, and $99 \%$ of the plants from the susceptible parent ('BR-14 Mulato') presented different symptoms of CABMV (Table 1). Inoculation in generation $\mathrm{F}_{1}$ resulted in 35 resistant and 165 susceptible plants, indicating a recessive resistance. Among the 800 plants from population $\mathrm{F}_{2}$, resistance was detected in $221(28 \%)$ of them, while $579(72 \%)$ were classified as susceptible. These results point out to a segregation proportion of 1 resistant:3 susceptible (1 R:3 S), as expected for a recessive gene. The results from the chi-square test for generation $\mathrm{F}_{2}$ accepted the proportion $1 \mathrm{R}: 3 \mathrm{~S}$, admitting a recessive monogenic inheritance, supported by the segregation proportion of population $\mathrm{BC}_{\mathrm{R}}(1 \mathrm{R}: 1 \mathrm{~S})$ and $\mathrm{BC}_{\mathrm{S}}(0 \mathrm{R}: 1 \mathrm{~S})$. Among the 386 RILs of generation $\mathrm{F}_{7}$ subjected to the inoculation of CABMV, 212 were classified as susceptible and 174 as resistant. A segregation proportion of $1 \mathrm{R}: 1 \mathrm{~S}$ was observed, supporting the research of population $F_{2}$ and backcrossing. Therefore, the obtained results confirmed that cowpea presents a monogenic recessive resistance to CABMV.

By observing a continuous distribution of severity data in population $\mathrm{F}_{2}$ of cowpea, Orawu et al. (2013) also concluded that a single recessive gene conditions resistance to CABMV. Conversely, Antoine et al. (2016), when studying the inheritance and the relationship among alleles of resistance to CABMV in two cowpea genotypes (KVx640 and KVx396-4-52D), found that resistance is ruled by two dominant genes in both varieties, with each one contributing to one resistant gene.

For passion fruit (Passiflora edulis Sims and Passiflora setacea DC.), Freitas et al. (2015) reported that a polygenic inheritance to CABMV. The authors highlighted that the observed number of resistant and susceptible individuals obtained through backcrossing was significantly different than the expected. These findings differ from those of the present study, which assessed cowpea genotypes, in which the proportions between resistant and susceptible individuals were accepted for backcrossing. This varying behavior might be related to the different host species evaluated.

Plant resistance to several diseases caused by potyviruses, such as CABMV, has been related to factors produced by the host and that are required by RNA viruses within their life cycle, such as the translation initiation factor (eIF4E) (Chandrasekaran et al., 2016; Tavert-Roudet et al., 2017). This factor is related to cell-to-cell movement and viral replication. The VPg protein attached to the 5' end of the viral mRNA may act as a cap of cell mRNA and, therefore, interact with the eIF4E, promoting the synthesis of viral proteins. Mutations on the amino acids or VPg disable such interaction and lead to plant resistance due to the reduction or absence of virus replication.

Table 1. Analysis of segregation for resistance to Cowpea aphid-borne mosaic virus in populations derived from the crossing between a resistant (IT85F-2687) and a susceptible ('BR 14-Mulato') cowpea (Vigna unguiculata) genotype.

\begin{tabular}{|c|c|c|c|c|c|}
\hline \multirow[t]{2}{*}{ Population $^{(1)}$} & \multicolumn{2}{|c|}{ Number of plants } & \multirow{2}{*}{$\begin{array}{c}\text { Expected proportion } \\
\text { R:S }\end{array}$} & \multirow[t]{2}{*}{$\chi^{2}$} & \multirow{2}{*}{$\begin{array}{c}\text { Probability } \\
(\%)\end{array}$} \\
\hline & $\mathrm{R}$ & $\mathrm{S}$ & & & \\
\hline IT85F-2687 & 82 & 18 & $1: 0$ & - & - \\
\hline 'BR 14-Mulato' & 1 & 99 & $0: 1$ & - & - \\
\hline $\mathrm{F}_{1}$ & 35 & 165 & $0: 1$ & - & - \\
\hline $\mathrm{F}_{2}$ & 221 & 579 & $1: 3$ & $2.94 *$ & 8.64 \\
\hline $\mathrm{BC}_{\mathrm{R}}$ & 87 & 113 & $1: 1$ & $3.38^{*}$ & 6.60 \\
\hline $\mathrm{BC}_{\mathrm{s}}$ & 27 & 173 & $0: 1$ & $3.64 *$ & - \\
\hline RILs $\mathrm{F}_{7}^{(2)}$ & 174 & 212 & $1: 1$ & $3.74 *$ & 5.31 \\
\hline
\end{tabular}

${ }^{(1)}$ Backcrosses of $\mathrm{F}_{1}$ with the resistant parent $\left(\mathrm{BC}_{\mathrm{R}}\right)$ and with the susceptible parent $\left(\mathrm{BC}_{\mathrm{S}}\right)$. $^{(2)}$ Ten plants of each $386 \mathrm{RILs}$ (174 resistant and 212 susceptible) were inoculated. R, resistant; S, susceptible; $\chi^{2}$, chi-square test; and RILs, recombinant inbred lines. *Significant at $5 \%\left(\chi^{2}\right.$ calculated $<\chi^{2}$ tabulated equal to 3.84$)$. 
As the resistance to CABMV in line IT85F-2687 is ruled by a recessive gene, backcrossing is the best genetic improvement method to incorporate resistance into other cowpea genotypes with desirable agronomic traits (Leão et al., 2016). The results of the present study might lead to further genetic mapping research about this gene through the identification of related molecular markers that might be used in markerassisted selection.

\section{Acknowledgments}

To Instituto Agronômico de Pernambuco (IPA), for providing the used cowpea genotypes and the isolate of the Cowpea aphid-borne mosaic virus (CABMV).

\section{References}

ANTOINE, B.; SALLE, T.J.B. De La;ZAKARIA, D.; ZAKARIA, K.; LEANDRE, P.; MAHAMADOU, S. Inheritance and allelic relationship of resistance to Cowpea aphid-borne mosaic virus (CABMV) in two cowpea genotypes, KVX640 and KVX3964-5-2D, in Burkina Faso. International Journal of Current Microbiology and Applied Sciences, v.5, p.285-292, 2016. DOI: https://doi.org/10.20546/ijcmas.2016.508.030.

BARROS, G.B.; NOGUEIRA, M. do S. da R.; OLIVEIRA, C.R.R. de; FREIRE FILHO, F.R.; RIBEIRO, V.Q.; VEIGA, C.F. de M.; BRIOSO, P.S.T.; EIRAS, M. Obtenção de plantas de feijão-caupi resistentes ao Cowpea severe mosaic virus e ao Cowpea aphidborne mosaic virus. Summa Phytopathologica, v.39, p.130-136, 2013. DOI: https://doi.org/10.1590/S0100-54052013000200009.

BORÉM, A.; MIRANDA, G.V. Melhoramento de plantas. 6.ed. Viçosa: UFV, 2013.

BOUKAR, O.; BELKO, N.; CHAMARTHI, S.; TOGOLA, A.; BATIENO, J.; OWUSU, E.; HARUNA, M.; DIALLO, S.; UMAR, M.L.; OLUFAJO, O.; FATOKUN, C. Cowpea (Vigna unguiculata): genetics, genomics and breeding. Plant Breeding, v.138, p.415-424, 2019. DOI: https://doi.org/10.1111/pbr.12589.

CHANDRASEKARAN, J.; BRUMIN, M.; WOLF, D.; LEIBMAN, D.; KLAP, C.; PEARLSMAN, M.; SHERMAN, A.; ARAZI, T.; GAL-ON, A. Development of broad virus resistance in non-transgenic cucumber using CRISPR/Cas9 technology. Molecular Plant Pathology, v.17, p. 1140-1153, 2016. DOI: https://doi.org/10.1111/mpp.12375.

CRUZ, C.D. GENES: a software package for analysis in experimental statistics and quantitative genetics. Acta
Scientiarum. Agronomy, v.35, p.271-276, 2013. DOI: https://doi.org/10.4025/actasciagron.v35i3.21251.

FREITAS, J.C.O.; VIANA, A.P.; SANTOS, E.A.; SILVA, F.H.L.; PAIVA, C.L.; RODRIGUES, R.; SOUZA, M.M.; EIRAS, M. Genetic basis of the resistance of a passion fruit segregant population to Cowpea aphid-borne mosaic virus (CABMV). Tropical Plant Pathology, v.40, p.291-297, 2015. DOI: https://doi.org/10.1007/s40858-015-0048-2.

LEÃO, U.S.; EIRAS, M.; FREIRE FILHO, F.R.; NOGUEIRA, M. do S. da R.; RODRIGUES, L.K.; RIBEIRO, V.Q.; LOPES, A.C. de A. Selection of phenotypic traits and resistance to Cowpea severe mosaic virus and Cowpea aphid-borne mosaic virus in cowpea [Vigna unguiculata (L.) Walp.] seeds with rugose white coat. Australian Journal of Crop Science, v.10, p.470-481, 2016. DOI: https://doi.org/10.21475/ajcs.2016.10.04.p7101x.

LIMA FILHO, A.F.; COELHO FILHO, M.A.; HEINEMANN, A.B. Determinação de épocas de semeadura do feijão caupi no Recôncavo Baiano através do modelo CROPGRO. Revista Brasileira de Engenharia Agrícola e Ambiental, v.17, p.1294-1300, 2013. DOI: https://doi.org/10.1590/S141543662013001200007.

LIMA, J.A.A.; SILVA, A.K.F. da; ARAGÃO, M. do L.; FERREIRA, N.R. de A.; TEÓFILO, E.M. Simple and multiple resistances to viruses in cowpea genotypes. Pesquisa Agropecuária Brasileira, v.46, p.1432-1438, 2011. DOI: https://doi.org/10.1590/S0100-204X2011001100003.

OLIVEIRA, C.R.R. de; FREIRE FILHO, F.R.; NOGUEIRA, M. do S. da R.; BARROS, G.B.; EIRAS, M.; RIBEIRO, V.Q.; LOPES, A.C. de A. Reação de genótipos de feijão-caupi revela resistência às coinfecções pelo Cucumber mosaic virus, Cowpea aphid-borne mosaic virus e Cowpea severe mosaic virus. Bragantia, v.71, p.59-66, 2012. DOI: https://doi.org/10.1590/ S0006-87052012005000007

ORAWU, M.; MELIS, R.; LAING, M.; DERERA, J. Genetic inheritance of resistance to Cowpea aphid-borne mosaic virus in cowpea. Euphytica, v.189, p.191-201, 2013. DOI: https://doi.org/10.1007/s10681-012-0756-3.

TAVERT-ROUDET, G.; ANNE, A.; BARRA, A.; CHOVIN, A.; DEMAILLE, C.; MICHON, T. The potyvirus particle recruits the plant translation initiation factor eIF4E by means of the Vpg covalently linked to the viral RNA. Molecular Plant-Microbe Interactions, v.30, p.754-762, 2017. DOI: https://doi.org/10.1094/ MPMI-04-17-0091-R

VALE, C.C.; LIMA, J.A.A. Efeitos de infecções isoladas e misturas de vírus de grupos distintos em caupi. Fitopatologia Brasileira, v.19, p.193-197, 1994.

ZARY, K.W.; MILLER JUNIOR, J.C. Comparison of two methods of hand-crossing Vigna unguiculata (L.) Walp. HortScience, v.17, p.246-248, 1982. 